\title{
RADICALISATION AND COUNTER- RADICALISATION IN HIGHER EDUCATION
}


Great Debates in Higher Education is a series of short, accessible books addressing key challenges to and issues in Higher Education, on a national and international level. These books are research informed but debate driven. They are intended to be relevant to a broad spectrum of researchers, students and administrators in higher education, and are designed to help us unpick and assess the state of higher education systems, policies and social and economic impacts.

\section{Published titles:}

Teaching Excellence in Higher Education: Challenges, Changes and the Teaching Excellence Framework Edited by Amanda French and Matt O'Leary

British Universities in the Brexit Moment: Political, Economic and Cultural Implications

Mike Finn

Sexual Violence on Campus: Power-Conscious Approaches to Awareness, Prevention, and Response

Chris Linder

Higher Education, Access and Funding: The UK in International Perspective

Edited by Sheila Riddell, Sarah Minty, Elisabet Weedon, and Susan Whittaker

Evaluating Scholarship and Research Impact: History, Practices, and Policy Development

Jeffrey W. Alstete, Nicholas J. Beutell, and John P. Meyer

Access to Success and Social Mobility through Higher Education: A Curate's Egg?

Edited by Stuart Billingham 
The Marketisation of English Higher Education: A Policy Analysis of a Risk-Based System

Colin McCaig

Refugees in Higher Education: Debate, Discourse and Practice

Jacqueline Stevenson and Sally Baker

Forthcoming titles:

Cultural Journeys in Higher Education: Student Voices and Narratives

Jan Bamford and Lucy Pollard 
This page intentionally left blank 


\section{RADICALISATION AND COUNTER- RADICALISATION IN HIGHER EDUCATION BY}

CATHERINE MCGLYNN University of Huddersfield, UK AND

SHAUN MCDAID

University of Huddersfield, UK

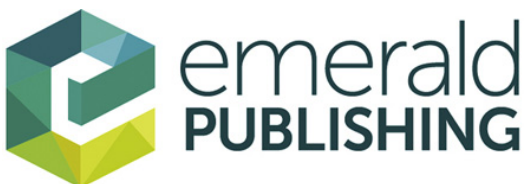

United Kingdom - North America - Japan India - Malaysia - China 
Emerald Publishing Limited

Howard House, Wagon Lane, Bingley BD16 1WA, UK

First edition 2019

Copyright (C) 2019 Catherine McGlynn and Shaun McDaid Published under an exclusive licence

\section{Reprints and permissions service}

Contact: permissions@emeraldinsight.com

No part of this book may be reproduced, stored in a retrieval system, transmitted in any form or by any means electronic, mechanical, photocopying, recording or otherwise without either the prior written permission of the publisher or a licence permitting restricted copying issued in the UK by The Copyright Licensing Agency and in the USA by The Copyright Clearance Center. Any opinions expressed in the chapters are those of the authors. Whilst Emerald makes every effort to ensure the quality and accuracy of its content, Emerald makes no representation implied or otherwise, as to the chapters' suitability and application and disclaims any warranties, express or implied, to their use.

British Library Cataloguing in Publication Data

A catalogue record for this book is available from the British Library

ISBN: 978-1-78756-005-5 (Print)

ISBN: 978-1-78756-002-4 (Online)

ISBN: 978-1-78756-004-8 (Epub)

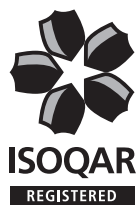

Certificate Number 1985

ISO 14001
ISOQAR certified Management System, awarded to Emerald for adherence to

Environmental standard ISO 14001:2004. 


\section{ACKNOWLEDGEMENTS}

We thank the team at Emerald Publishing for the opportunity to write this book, especially Dr Philippa Grand and Kimberley Chadwick. Our research was conducted with the help of a Research and Innovation Fund grant from the University of Huddersfield and we would like to thank Professor Surya Munro, Director of the Centre for Citizenship, Conflict, Identity and Diversity, Professor Brid Featherstone, Head of the Department of Behavioural and Social Sciences and Dr Pete Woodcock, Head of the Division of Criminology, Politics and Sociology for their support. Special thanks goes to Susan Smith whose efforts made the task of analysing transcripts a pleasant one. The book has benefitted from the insights of friends and colleagues too numerous to mention - thank you all. We are exceptionally grateful to the lecturers and students who gave their time willingly as participants in our focus groups. Catherine dedicates this book with love to Ian, Rachel and Louise. Shaun dedicates it to Ania and to Emilia. 
This page intentionally left blank 


\section{CONTENTS}

List of Acronyms $\quad$ xi

About the Authors xiii

1. Introduction 1

2. Radicalisation: Debate and Policy 11

3. Universities, Terrorism and Radicalisation 41

4. Radicalisation and HE governance 75

5. Radicalisation and the University Classroom 111

6. Conclusion and Recommendations 145

References 159

$\begin{array}{ll}\text { Index } & 191\end{array}$ 
This page intentionally left blank 


\section{LIST OF ACRONYMS}

AM Al-Muhajiroun (The Emigrants)

AQAP Al-Qaeda in the Arabian Peninsula

BCU Birmingham City University

CTSA Counterterrorism and Security Act 2015

EDL English Defence League

ERG22 + Extremism Risk Guidelines/Guidance

ETA Euskadi ta Askatasuna (Basque Homeland and Freedom)

FOSIS Federation of Student Islamic Societies

HE Higher Education

HEFCE Higher Education Funding Council for England

HEI Higher Education Institutions

HT Hizb ut-Tahrir

IRA Irish Republican Army

IS Islamic State Group

JIMAS Jamiyat Ihya Minhaj al-Sunnah (Association to Revive the Way of the Messenger)

LSE London School of Economics

LUU Leeds University Union

MB Muslim Brotherhood

MSS Muslim Students Society

NICRA Northern Ireland Civil Rights Association 
NIRT Northern Ireland Related Terrorism

NUS National Union of Students

PD People's Democracy

PLO Palestinian Liberation Organisation

RAF Rote Armee Fraktion (Red Army Faction)

RCMP Royal Canadian Mounted Police

SDS Sozialistischer Deutsche Studentenbund (Socialist German Students' League)

SOAS School of Oriental and African Studies

UAL University of the Arts London

UCU University and College Union

UKIM United Kingdom Islamic Mission

WRAP Workshop to Raise Awareness of Prevent 


\section{ABOUT THE AUTHORS}

Catherine McGlynn is Senior Lecturer in Politics at the University of Huddersfield, UK. Her research focuses on Northern Ireland with respect to conflict resolution and party politics. Her last book was Abandoning Historical Conflict? Former Paramilitary Prisoners and Political Reconciliation in Northern Ireland from Manchester University Press (coauthored with Peter Shirlow, Jonathan Tonge and James W. McAuley) which was the Political Studies Association of Ireland Book of the year in 2011.

Shaun McDaid is Senior Lecturer in Politics at the University of Huddersfield, UK. His research and teaching interests include the conflict in Northern Ireland, but also the dynamics of political violence and attempts to prevent it more generally. $\mathrm{He}$ is the author of Template for Peace: Northern Ireland, 1972-1975 (Manchester University Press, 2013), and is a Fellow of the Royal Historical Society. 
This page intentionally left blank 


\section{CHAPTER 1}

\section{INTRODUCTION}

In February 2015, the Counter-Terrorism and Security Act (CTSA) was passed by the British Parliament (HM Government, 2015a). The act encompasses a broad range of powers, covering everything from the seizure of passports of terrorism suspects to transport security. One of its more controversial aspects, however, was the creation of a legal duty to have 'due regard to prevent people from being drawn into terrorism' (hereafter the 'Prevent Duty') which applied to a range of public bodies, including higher education institutions (HEIs). To comply with the legislation, universities were required to develop systems to monitor the potential propagation of what are deemed to be extremist ideas, for instance having policies on external speakers and the acceptable use of Information Technology infrastructure.

The logic underpinning the duty was that individuals who commit acts of terrorism, or join terrorist groups, undergo a process of 'radicalisation' prior to such engagement, and that, in higher education, university staff are uniquely placed to spot the potential students who may be experiencing this. Radicalisation is essentially seen as a pathway towards violent extremism (see e.g. McCauley \& Moskalenko, 2008; 
Taylor \& Horgan, 2006; Neumann, 2013). Put simply, it has been defined as the processes that happen 'before the bomb goes off' (Sedgwick, 2010, p. 479). Radicalisation is inextricably linked to the concept of extremism, and the latter is usually seen as a precursor to the former.

Successive UK governments have been keen advocates of the theory of radicalisation, and, along with Belgium and the Netherlands, early adopters of strategies to deter it. In the UK, counter-radicalisation falls under the PREVENT strategy (HM Government, 2011a), which was part of its overall counter-terrorism strategy (CONTEST) along with PURSUE, PROTECT and PREPARE. Universities are, and have been, regarded as potentially risky areas where students could be drawn into terrorism by active recruiters. If such students showing signs of radicalisation can be spotted, so the argument runs, they could potentially be referred to the government's (voluntary) counter-radicalisation programme, Channel and 'de-radicalised', thus saving themselves, and others, from the consequences of engaging in violence.

The political context that surrounds the creation of the Prevent Duty was the rise of the Islamic State (IS) group, which emerged from the chaos following the Iraq war, insurgency and occupation. IS, a recalcitrant off-shoot of AlQaeda which began operations in Iraq and Syria, declared a Caliphate at the al-Nuri mosque in Mosul in 2014. The group's leader, Abu Bakr al-Baghdadi, argued that there was a religious duty on Muslims to hasten to the region in defence of the newly declared Caliphate (Stern \& Berger, 2015). This prompted an influx of foreign fighters to the region, primarily from the Middle-East and North Africa. However, significant numbers of Europeans, predominantly young males, fled to fight jihad, especially in Syria, which since 2011 has been in the grip of civil war between the regime of Bashar al-Assad (backed by Russia, Iran and the latter's Lebanese proxies, 
Hezbollah) and a rag-tag of rebel groups, including a Syrian Al-Qaeda franchise (Lister, 2015). According to recent research, approximately 850 British nationals have gone to Syria, and about half of these have since returned (Barrett, 2017). For policy-makers, therefore, there are two key challenges: what to do with those who have been away and returned, and how to stop them going there in the first place?

The Syrian civil war has not been the only factor in the ascent of counter-radicalisation to a position of centrality in contemporary counter-terrorism, and concerns about extremism and radicalisation of university students predate the creation of the Prevent Duty. Much media attention has been paid to the fact that a number of jihadists have been educated at UK universities, including Mohammed 'Jihadi John' Emwazi, Michael Adebolajo, one of the killers of Fusilier Lee Rigby, and Mohammed Awan, the Sheffield dentistry student convicted of terrorist offences in 2017, to name but a few. This, combined with the contemporary political developments outlined above, saw an increasing scrutiny of universities as potential sites where people could be drawn into terrorism.

Warnings about the attractiveness of university students as potential recruits, and of university campuses as places for extremist groups to organise have featured in security discussions about contemporary terrorist threats. A New York Police Department report on radicalisation, for example, claimed that middle-class 'clean skins' at British universities were sought after by local extremists (Silber \& Bhatt, 2007, p. 85). Furthermore, the UK Association of Chief Police Officers (ACPO) warned in Prevent guidance documentation that more than 30 per cent of those convicted of Al-Qaedarelated offences between 1999 and 2009 had been to university, and that extremist groups were targeting campuses (ACPO, 2012). It should come as little surprise, therefore, 
that government, on receipt of these warnings, should begin to regard the higher education sector as an arena for scrutiny.

The introduction of the Prevent Duty has, however, attracted considerable controversy, and raised a number of pertinent questions for academics and policy-makers alike (Lewis, 2018). One of the key criticisms of the duty, and PREVENT policy in general, is that it could lead to undue state interference in an arena where it is perfectly normal for radical, and even potentially offensive ideas, to be explored, debated or researched (see e.g. Spiller, Awan, \& Whiting, 2018). In this view, universities are seen as arenas where free speech and expression should be the norm, and students able to freely engage in debate. Critics of the duty see university staff taking an active part in the facilitation of this free exchange of ideas, and are concerned that the duty may cast them in the role of 'thought police', resulting in a 'chilling effect' on free and open debate. To the contrary, there are those who argue that the duty is, in itself, nothing to worry about and largely based on misconceptions about what PREVENT does (Greer \& Bell, 2018).

Advocates of university counter-radicalisation initiatives, including the government, contend that it is particularly important to have policies and procedures in place during what for many young adults is a transitional period in their lives. A report for the European Commission found that university campuses were not direct recruiting grounds for violent extremisms, rather it was where 'gateway organisations' could draw people into a process of radicalisation (Neumann \& Rogers, 2008, p. 45). The report observed that 'there can be no doubt that universities have always been 'hotbeds' for radical thought, and that - like prisons and asylum reception centres - they are places in which individuals are prone to experience feelings of isolation and vulnerability' (Neumann \& Rogers, 2008, p. 45). These themes of 
exposure to ideas, of processes of radicalisation and of crisis points for the vulnerable are, as we will show, crucial to how radicalisation and counter-radicalisation have been operationalised in currently policy-making. The notion of vulnerability is particularly important to these narratives, where the tumult of the undergraduate experience could see students struggle to cope with changes in identity, status or social and familiar relations to the extent that they may be susceptible to what is effectively a form of grooming by violent extremists. Interventionist counter-radicalisation initiatives are here portrayed as part of what we define as a 'safeguarding route' approach.

The safeguarding route portrays counter-radicalisation initiatives, which are an intrinsic part of counter-terrorism policy, as a proactive intervention, designed to protect vulnerable people. The would-be recruit is infantilised and stripped of personal agency, in ways that those who joined 'traditional' terrorist groups such as the Irish Republican Army (IRA) or Basque separatists Euskadi ta Askatasuna (ETA) never have been. Here, conventional notions of perpetrators and victims are turned on their heads, with a person who has become involved in violent extremism seen as little more than a lost soul in thrall to a nefarious recruiter, who carries responsibility for the young person's journey into terrorism.

Universities have thus become a key site of contestation in the debates about counter-terrorism and counterradicalisation policy and practice. Given the implications of these developments, which extend well beyond the domain of HEIs, it is crucial to understand more about the operation of the Prevent Duty on campuses, its impact on staff and students, which will in turn be useful to policy-makers tasked with implementing, improving or reviewing the duty.

This book is the first study which examines and contextualises these developments, with a focus on how the Prevent 
Duty is implemented in English Universities with reference to the experiences of both staff and students. The findings are drawn from the analysis of a range of new, original empirical research, including university policy documents and published correspondence to staff and students as well as focus group studies carried out with staff and undergraduate students enroled or employed at English HEIs. The focus groups involved both control groups, who had not studied or taught terrorism-related topics, and groups which had studied or taught these subjects.

As is detailed in subsequent chapters, the book uses a number of research methods to scrutinise this data, inspired by approaches in qualitative psychology, including a thematic analysis of the published documents of 106 English HEIs outlining how they comply with their statutory duties, and an interpretative phenomenological analysis (IPA) of four focus groups with staff and students sharing their experiences of teaching and learning in HEIs as the Prevent Duty took effect.

The choice of England as the research focus has a sound methodological imperative. Firstly, as one of our focus group participants pointed out, PREVENT is 'to all intents and purposes' an English strategy which has 'a tiny footprint in Cardiff [and] Swansea' in Wales (M3, male). CONTEST recognises the threat of Northern Ireland related terrorism (NIRT), but the Prevent Duty is not applied in universities in Northern Ireland, nor does Northern Ireland have a Prevent strategy per se. Equally, the policy has little traction in Scotland. Secondly, education policy in the UK has always been subject to considerable sub-state variation. Funding and policy for HEIs has diverged further since the advance of devolution in the late-1990s, creating a distinctly English educational experience in the part of the state that PREVENT is most firmly focused. 
This, coupled with the fact that English HEIs are now among the most expensive in the world, means they are subject to many performance management measures that put an emphasis on students as consumers, in a marketised system (Molesworth, Nixon, \& Scullion, 2009). We argue that these two frameworks for English HEIs complement each other, and that an ethos that universities provide a service, articulated as the student experience, underpins the safeguarding route approach to radicalisation, the genesis and implications of which we will systematically outline in this work.

Whilst the geographical focus of the research is on English HEIs, the findings of the book have implications that span well beyond the United Kingdom. The UK is a pioneer of counter-radicalisation in a university environment, and its experiences have much to teach policy-makers, and academics interested in radicalisation and its prevention, in other national settings. The UK is often referred to in the policy documents of other states in this regard. In this respect, our study is a particularly timely one, since it coincides with the recent rollout, or examination of the potential to implement, counter-radicalisation initiatives in universities in several other countries. In North America, the United States government sees universities as forming a central part of the government's countering violent extremism (CVE) initiatives, assisting local communities in building capacity in this area, and seeks to engage university students in efforts to counter violent extremist messages (Stewart, 2017; White House, 2015). Likewise, Canadian government funding for countering radicalisation to violence $(\mathrm{CRV})$ is available to universities and other educational institutions (Public Safety Canada, 2017).

In Asian countries which have suffered a great deal from political violence, such efforts are also being expanded. The Higher Education Commission for Pakistan urged universities 
to develop protocols to tackle the radicalisation of students (The News, 2017), and in Indonesia, universities have agreed to collaborate with state security agencies to monitor campus activities (Times Higher Education, 2018). Critics could, of course, justifiably point to concerns about the actions of state security services in both countries, and their suitability to monitor educational institutions. Closer to home, the Norwegian government has begun investigating the ways by which universities can contribute to the fight against radicalisation and extremism among students in the higher education sector (Kingdom of Norway, 2017; Wille, 2017). Thus, research on the experiences of universities in England, where the Prevent Duty has been in operation for three years, can provide academics and practitioners with valuable insights into the strengths and weaknesses of the policy, offering the potential to improve any interventions in other national settings. But it is not just in the arena of social policy that the book makes a contribution; it also engages with broader debates of international significance, as the following chapter outlines demonstrate.

\section{STRUCTURE AND CONTRIBUTION}

The purpose of the book is not only to present the findings of new research into the implementation of the Prevent Duty and its impact on university staff and students. It also seeks to situate this discussion alongside broader debates concerning the nature of radicalisation and the efficacy of attempts to counter it, and to demonstrate that universities - across a range of national settings - have long been sites of radical political activity, but also arenas where states have intervened and surveilled, justified in terms of public safety and security. 